Al-Madrasah: Jurnal Ilmiah Pendidikan Madrasah Ibtidaiyah

Vol. 6, No. 1, 2022

DOI 10.35931/am.v6i1.894

P-ISSN: 2620-5807; E-ISSN: 2620-7184

\title{
MENILIK IMPLEMENTASI QANUN PEMERINTAH DAERAH DALAM PENANGANAN DAN PERLINDUNGAN TERHADAP KEKERASAN ANAK DI ACEH
}

\author{
Anggi Putri", Hardi Alunaza, Desy Nur Shafitri*, Annisa Ernianda*, Mentari \\ Prodi Hubungan Internasional FISIP Universitas Tanjungpura \\ Koresponden Email : hardi.asd@fisip.untan.ac.id
}

\begin{abstract}
Abstrak
Tujuan penelitian ini dilakukan untuk melihat bagaimana implementasi qanun pemerintah dalam menangani kasus kekerasan pada adai di provinsu Aceh. Kasus kekerasan pada anak di Aceh meningkat secara signifikan setiap tahunnya baik kekerasan fisik maupun seksual. Penanganan pemerintah daerah Aceh menjadi sorotan bagaimana kinerja dan peraturan yang diterapkan untuk menekan laju kasus kekerasan anak di daerah tersebut. Aceh dengan regulasi khususnya menerapkan Qanun sebagai sumber hukum untuk penanganan setiap permasalahan termasuk perlindungan anak. Namun peraturan Qanun menimbulkan beberapa kebingungan karena dianggap memberikan hukuman yang relatif rendah untuk kejahatan kekerasan pada anak. Lebih lanjut penulisan ini akan melihat bagaimana implementasi Qanun tersebut sebagai peraturan yang juga memiliki andil besar Aceh. Penelitian kualitatif ini dilakukan dengan metode pendekatan deskriptif analitik untuk menganalisis permasalahan yang diangkat. Penulis akan menganalisis keberhasilan Qanun dengan berfokus kepada penanganan kasus perlindungan kekerasan anak oleh pemerintah daerah setempat,untuk mengetahui bagaimana peran Qanun apakah menyelesaikan kasus kekerasan psikis, fisik dan seksual pada anak di Aceh.
\end{abstract}

Kata Kunci: Qanun Aceh, Kekerasan Anak, Perlindungan Anak

\section{PENDAHULUAN}

Pelanggaran norma-norma hidup saat ini semakin marak terjadi di berbagai wilayah termasuk Indonesia. Tindak kejahatan menjadi hal yang tidak awam lagi dalam tatanan kehidupan bermasyarakat sehingga banyak didapati individu yang tidak segan untuk melakukan kejahatan yang akan menyakiti psikis, mental maupun fisik seseorang dengan tindak kejahatan yang dilakukan secara verbal maupun fisik. Saat ini salah satu sasaran dari tindak kejahatan yang dapat dikatakan memiliki persentase yang cukup tinggi adalah tindakan kekerasan secara fisik, kekerasan seksual dan kekerasan emosional yang ditujukan kepada anak-anak.

Dalam sebuah penelitian yang dilakukan oleh Kurniasari dkk pada tahun 2017, survei yang dilakukan pada penelitian prevalensi kekerasan anak menunjukkan bahwa di Indonesia kekerasan terhadap anak cukup banyak terjadi. Yakni dengan tingkat persentase 3,02\% kejahatan anak dengan

Al-Madrasah: Jurnal Ilmiah Pendidikan Madrasah Ibtidaiyah

Vol. 6, No. 1, Januari-Maret 2022 
Anggi Putri, Hardi Alunaza, Desy Nur Shafitri, Annisa Ernianda : Menilik Implementasi Qanun Pemerintah Daerah Dalam Penanganan dan Perlindungan Terhadap Kekerasan Anak di Aceh

artian bahwa per 10.000 anak di Indonesia kurang lebih sekitar 300 anak pernah mengalami tindak kekerasan di Indonesia, survei khusus yang dilakukan di beberapa provinsi yaitu Jawa Tengah, Nusa tenggara Timur, Aceh dan Papua menunjukkan bahwa tindak kekerasan anak dalam rumah tangga memiliki persentase $40-80$ persen di wilayah tersebut dengan pelaku tindak kekerasan adalah anggota keluarga. ${ }^{1}$

Pada tahun 2019-2021 Kementerian Perlindungan Perempuan dan Anak menyatakan bahwa tren kekerasan terhadap anak mengalami peningkatan yang cukup signifikan dari waktu ke waktu. Dihimpun dari data KemenPPPA bahwa pada tahun 2019 terdapat sebanyak 11.057 kasus kekerasan terhadap anak diikuti dengan selisih jumlah yang tidak terlalu banyak pada tahun 2020 yaitu berada di angka 11.279 kasus dan mengalami peningkatan yang cukup tinggi pada tahun 2021 yaitu mencapai 12.566 kasus kekerasan yang terjadi terhadap anak-anak, kasus kekerasan yang paling terbuka adalah kekerasan seksual dengan persentase kasus sebanyak 45 persen, kemudian sekitar 18 persen pada kekerasan fisik dan 19 persen pada kekerasan psikologis. ${ }^{2}$

Berikut terdapat data mengenai kekerasan Anak yang dimuat dari SIMFONI-PPA pada tahun 2021 dengan rasio korban kekerasan per 10.000 anak di setiap Provinsi di Indonesia.

Gambar 1. Jumlah Korban Kekerasan Anak tahun 2021 di Indonesia

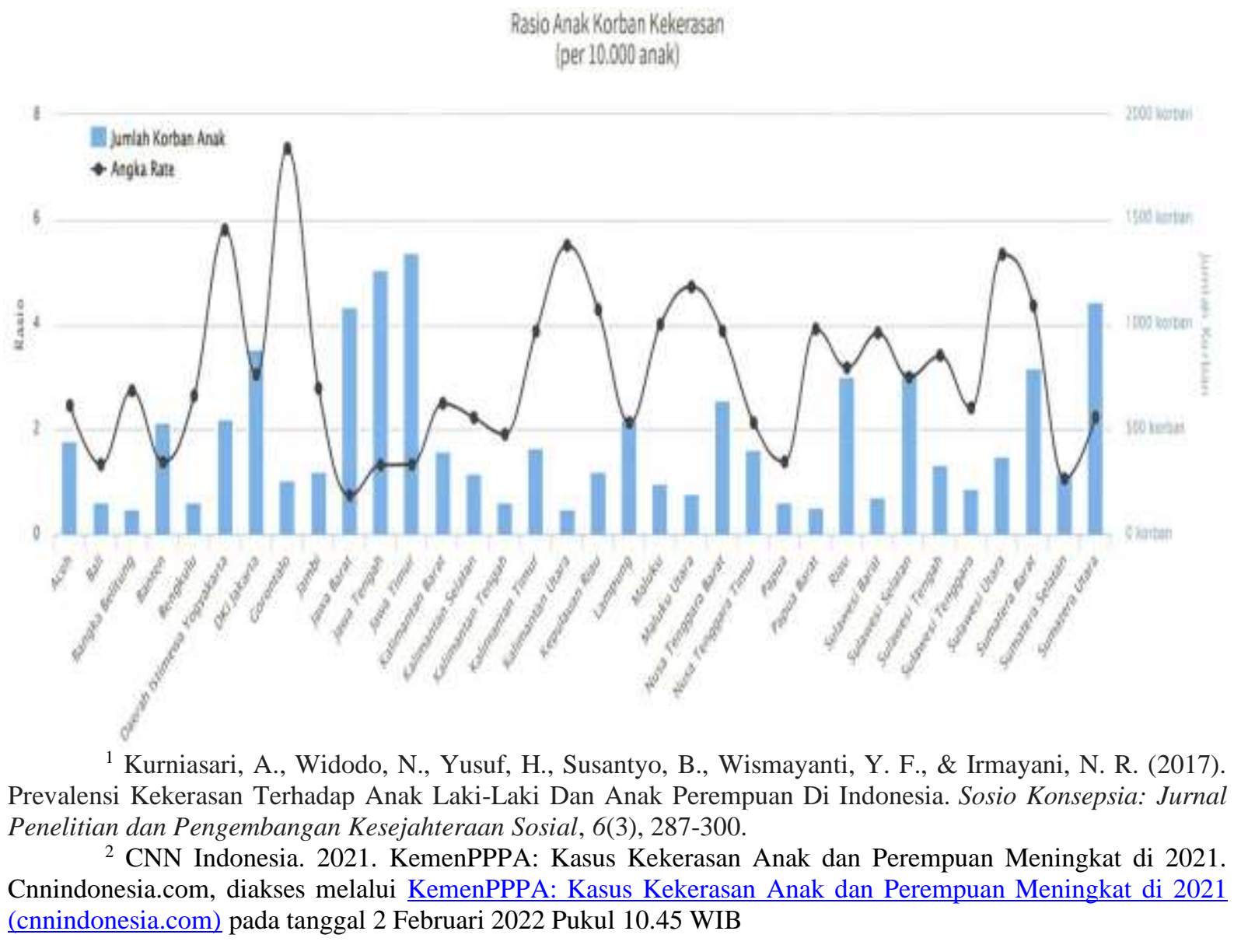

Al-Madrasah: Jurnal Ilmiah Pendidikan Madrasah Ibtidaiyah

Vol. 6, No. 1, Januari-Maret 2022 
Anggi Putri, Hardi Alunaza, Desy Nur Shafitri, Annisa Ernianda : Menilik Implementasi Qanun Pemerintah Daerah Dalam Penanganan dan Perlindungan Terhadap Kekerasan Anak di Aceh

\section{Sumber: SIMFONI-PPA Kemenpppa.go.id}

Lebih lanjut jumlah dari kekerasan anak di setiap provinsi dari grafik di atas adalah Aceh 444 korban, Bali 156 korban, Bangka Belitung 120 korban, Banten 538 korban, Bengkulu 157 korban, Yogyakarta 550 korban, DKI Jakarta 881 korban, Gorontalo 881, Jambi 302 korban, Jawa Barat 1.088 korban, Jawa Tengah 1.262 korban, Jawa Timur 1.347 korban, Kalimantan Barat 395 korban, Kalimantan Selatan 293 korban, Kalimantan Tengah 153 korban, Kalimantan Timur 416 korban, Kalimantan Utara 122 korban, Kepulauan Riau 298 korban, Lampung 550 korban, Maluku 240 korban, Maluku Utara 195 korban, Nusa Tenggara Barat 642 korban, Nusa Tenggara Timur 402 korban, Papua 152 korban, Papua Barat 128 Korban, Riau 756 korban, Sulawesi Barat 176 korban, Sulawesi Selatan 778 korban, Sulawesi Tengah 329, Sulawesi Tenggara 222 korban, Sulawesi Utara 375 korban, Sumatera Barat 793, Sumatera Selatan 288 korban, Sumatera Utara 1.106 korban.

Aceh menjadi salah satu provinsi dengan tindak kekerasan anak yang belum dapat dikatakan pada tingkat kejahatan yang rendah. Masih banyak didapati kekerasan yang dilakukan terhadap anakanak untuk setiap tahunnya. Pada tahun 2020 tindak kekerasan terhadap anak di Aceh menunjukkan angka yang cukup tinggi yaitu sebanyak 464 kasus diikuti dengan 420 kasus kekerasan yang terjadi kepada perempuan. ${ }^{3}$ Salah satu bentuk kekerasan anak dengan kasus yang cukup tinggi di antara kasus lainnya di Aceh adalah pelecehan seksual terhadap anak. YLBHI-LBH Banda Aceh menyatakan bahwa sepanjang tahun 2021 dalam rentang waktu 18 jam 45 menit satu anak dinyatakan menjadi sasaran dari kekerasan seksual sehingga dari kalkulasi yang didapatkan dari bulan Januari hingga September jumlah kasus kekerasan seksual terhadap anak terjadi sebanyak 355 kasus di Provinsi Aceh tersebut. ${ }^{4}$

Tren kekerasan terhadap anak harus menjadi salah satu perhatian utama bagi semua pihak utamanya pemerintahan sebagai pihak yang dapat membentuk kebijakan terhadap pelaku-pelaku dari tindak kejahatan tersebut agar kekerasan anak di suatu wilayah lebih dapat diminimalisir dari waktu ke waktu. Bentuk peraturan dalam undang-undang yang dijalankan Aceh tidak hanya merujuk kepada peraturan nasional saja, namun juga terdapat undang-undang khusus yang dijalankan di Aceh dengan sebutan Qanun. Beriringan dengan undang-undang nasional, Aceh juga menjalankan aturan khususnya atau Qanun salah satunya dalam menangani kasus kekerasan anak yang terjadi di Aceh.

\footnotetext{
${ }^{3}$ Devi Purnama Sari. 2021. Data Kasus Kekerasan terhadap Perempuan dan Anak di Aceh Tahun 2020. Opendata, diakses melalui Data Kasus Kekerasan terhadap Perempuan dan Anak di Aceh Tahun 2020 - Datasets - OpenData Aceh (acehprov.go.id) pada tanggal 2 Februari 2022 pukul 17.20 WIB.

${ }^{4}$ Rino Abonita. 2021. Setiap 18 Jam 45 Menit, Satu Anak di Aceh Jadi Korban Kekerasan Seksual. Liputan6.com, diakses melalui Setiap 18 Jam 45 Menit, Satu Anak di Aceh Jadi Korban Kekerasan Seksual Regional Liputan6.com pada tanggal 2 Februari 2022 Pukul 21.04 WIB.
}

Al-Madrasah: Jurnal Ilmiah Pendidikan Madrasah Ibtidaiyah

Vol. 6, No. 1, Januari-Maret 2022 
Anggi Putri, Hardi Alunaza, Desy Nur Shafitri, Annisa Ernianda : Menilik Implementasi Qanun Pemerintah Daerah Dalam Penanganan dan Perlindungan Terhadap Kekerasan Anak di Aceh

Sebagaimana peraturan yang tertera dalam Qanun Aceh Nomor 11 Tahun 2008 mengenai Perlindungan Anak. Qanun yang dibentuk oleh pemerintahan Aceh untuk perlindungan anak ini diyakini sebagai komitmen dan kesepakatan dari pemerintahan maupun komponen masyarakat lain untuk memberikan bentuk perlindungan yang sebaik-baiknya terhadap anak-anak Aceh yang juga merupakan generasi penerus bangsa. Di samping itu pembentukan Qanun Perlindungan Anak juga ditunjukkan sebagai bentuk manifestasi dari tanggung jawab Pemerintahan Aceh terhadap undangundang nasional tentang perlindungan anak tepatnya UU No. 23 tahun 2002 yang kemudian telah diubah menjadi UU Nomor 35 tahun 2014 tentang perlindungan anak dan sebagai upaya dari Pemerintahan Aceh yang juga mendukung dan berupaya menerapkan prinsip-prinsip Konvensi Anak PBB yang telah diadopsi oleh Indonesia melalui Keputusan Presiden Nomor 39 Tahun 1990. ${ }^{5}$

Bentuk kepedulian Pemerintahan Aceh sebagai Pemerintahan yang berlandaskan pada Syariat Islam ini dalam mengupayakan perlindungan terhadap kekerasan anak melalui Qanun tersebut cukup dapat diakui. Akan tetapi tingkat keefektifan dari Qanun yang diberlakukan dalam menyelesaikan kasus-kasus kekerasan anak di Aceh belum dapat dikatakan telah memberikan hasil maksimal. Masih didapati kasus-kasus kekerasan terhadap anak yang belum dapat diselesaikan melalui Qanun Aceh sehingga pemerintahan kembali merujuk atau lebih memilih untuk menggunakan peraturan perundang-undangan nasional dalam menyelesaikan masalah-masalah tersebut.

\section{TINJAUAN PUSTAKA}

Dalam melakukan penelitian mengenai Qanun Pemerintahan Aceh tentunya terdapat pijakan yang dijadikan penulis sebagai tinjauan pustaka dalam meneliti permasalahan ini. Penelitian sebelumnya yang berkaitan dan sesuai dengan isu yang penulis angkat yaitu mengenai perlindungan dan penanganan kasus kekerasan anak serta implementasi penerapan hukuman yang ada di Aceh akan dijelaskan melalui dua penelitian yang telah diteliti oleh penulis-penulis terdahulu.

Penelitian pertama ialah tulisan yang ditulis oleh Pocut Ismyati Vonda dan Cut Dian Fitri pada tahun 2017 dengan judul "Pelaksanaan Perlindungan Anak di Kota Banda Aceh." Penelitian ini membahas mengenai Peraturan perlindungan anak di kota Banda Aceh sebagaimana peraturan Qanun pemerintah daerah tersebut. Khususnya dalam kasus perlindungan anak diatur dalam Qanun Aceh No.11 Tahun 2008 tentang Perlindungan Anak. Penulis memfokus bagaimana penanganan yang telah pemerintah daerah lakukan untuk mengurangi kasus kekerasan pada anak. Hasil penulisan di perlihatkan bahwa pemerintah telah menyiapkan perlindungan anak di Banda Aceh dengan memperkuat peraturan yang ada dan mengendalikan pendudukan serta keluarga berencana. Penulis

${ }^{5}$ Ida Friatna (2019). Perlindungan Anak dalam Perspektif Hukum Islam dan Qanun Aceh Nomor 11 Tahun 2008. Gender Equality: International Journal of Child and Gender Studies, 5(2), 66.

Al-Madrasah: Jurnal Ilmiah Pendidikan Madrasah Ibtidaiyah

Vol. 6, No. 1, Januari-Maret 2022 
Anggi Putri, Hardi Alunaza, Desy Nur Shafitri, Annisa Ernianda : Menilik Implementasi Qanun Pemerintah Daerah Dalam Penanganan dan Perlindungan Terhadap Kekerasan Anak di Aceh

menerangkan visi kantor Dinas Pemberdayaan Perempuan, Perlindungan Anak, Pengendalian Penduduk dan Keluarga Berencana (PPKB) yaitu mewujudkan kondisi perempuan dan anak yang bermartabat dan lingkungan keluarga sesuai syariat islam dengan penerapan 6 misi terkait perlindungan anak.

Penelitian kedua ialah tulisan yang berjudul "Perlindungan Hukum Terhadap Anak Korban Tindak Pidana Sodomi (Studi Kasus di Desa Alue Buloh Aceh Timur).” Oleh Sapri Suhairu, Nurdin, dan Siti Sahara. Penelitian ini menjelaskan penanganan hukum secara khusus atas kasus kejahatan anak melalui pelecehan seksual sodomi. Sebelum memulai inti pembahasan, penulis menjelaskan satu kasus sodomi anak di Desa Alue Buloh Kabupaten Aceh Timur secara khusus. Inti pembahasan dalam penulisan ini terbagi atas tiga bagian, pertama yaitu penulis menjabarkan hukum apa saja yang berlaku mengenai kekerasan seksual sodomi anak kecil beserta denda yang harus diterima pelaku. Pada bagian kedua, menjabarkan satu persatu perlindungan hukum kepada korban sodomi di berbagai peraturan perundang-undangan. Terakhir, penulis menyampaikan bagaimana tindakan yang harus dilakukan pemerintah maupun keluarga untuk membantu anak-anak korban sodomi yaitu dengan pengelolaan korban melalui prevensi, terapi, rehabilitasi serta dukungan dari lingkungan keluarga dan masyarakat.

Dari kedua penelitian tersebut, penulis melihat bahwa belum ditemukannya data konkret seberapa banyak kasus kekerasan/pelecehan seksual sodomi anak-anak yang terjadi di Aceh setiap tahunnya. Penelitian pertama berfokus kepada hukum pidana terhadap pelaku namun tidak mengelaborasi kasus-kasus sebelumnya dari Aceh yang dapat memberikan gambaran bagaimana peraturan yang ada di Aceh dapat menyelesaikan permasalahan tersebut. Sedangkan penelitian kedua hanya memberikan contoh dari satu kasus korban sodomi. Penelitian sebelumnya kurang memberikan gambaran tepat bagaimana perkembangan kasus kekerasan pada di Aceh. Maka dari itu penelitian ini mencoba untuk mencari hal-hal yang tidak ditemukan dalam penelitian-penelitian sebelumnya. Kami akan menganalisis dan mengelaborasi data-data dari implementasi Qanun dalam penyelesaian kasus kekerasan anak yang terjadi di Aceh. Penelitian ini akan memaparkan peningkatan kasus kekerasan anak dan menegaskan bagaimana penanganan kekerasan anak melalui Qanun pemerintah daerah Aceh.

\section{METODOLOGI PENELITIAN}

Artikel ini menggunakan jenis penelitian kualitatif dengan menggunakan metode kepustakaan melalui penelitian hukum yang bersifat yuridis normatif. Penelitian ini akan menghimpun serta menginterpretasikan data-data yang didapatkan dari sumber yang valid dengan tujuan untuk

Al-Madrasah: Jurnal Ilmiah Pendidikan Madrasah Ibtidaiyah

Vol. 6, No. 1, Januari-Maret 2022 
Anggi Putri, Hardi Alunaza, Desy Nur Shafitri, Annisa Ernianda : Menilik Implementasi Qanun Pemerintah Daerah Dalam Penanganan dan Perlindungan Terhadap Kekerasan Anak di Aceh

membahas implementasi peraturan Qanun Aceh dalam menangani serta memberikan perlindungan terhadap kasus kekerasan anak yang terjadi di Aceh.

Dalam menuliskan artikel ini, penulis menggunakan pendekatan deskriptif analitik dimana penulis menggunakan teknik pengumpulan data sekunder dengan penghimpunan data dari sumber hukum yang berasal dari buku-buku, data statistik pemerintah, dokumen resmi, laporan-laporan dan konstitusi resmi. Utamanya dalam penelitian ini bersumber pada hukum Aceh (Qanun) yang menjadi sumber hukum islam di Aceh. Berikutnya penulis akan melihat bagaimana implementasi penggunaan Qanun dalam mengatasi permasalahan kekerasan anak di Aceh.

Analisis data dalam menuliskan artikel ini dilakukan melalui beberapa tahapan yaitu pertama pengumpulan data yang kemudian direduksi dengan berbagai teknik hingga menghasilkan data kasar yang akan diinterpretasikan sebagai olahan penulis dalam menjelaskan permasalahan yang diangkat. Kedua yaitu proses penyajian data yang ditampilkan secara terstruktur sehingga mampu menghasilkan kesimpulan yang mampu menampilkan keputusan sementara. Selanjutnya, keputusan-keputusan tersebut kemudian disajikan dengan bentuk teks deskriptif yang disertai penyajian diagram maupun bagan yang mampu menguatkan kredibilitas tulisan. Tahap terakhir yaitu melakukan penarikan hasil akhir dari analisis yang telah dilaksanakan dengan menyesuaikan realitas yang ada ${ }^{6}$.

\section{HASIL DAN PEMBAHASAN}

\section{Kasus Kekerasan Anak di Aceh}

Permasalahan kekerasan terhadap anak terutama kasus pelecehan seksual anak merupakan masalah yang berkaitan dengan masalah sosial, ekonomi, pembangunan, hukum, pendidikan, hak asasi manusia serta kesehatan fisik dan mental yang sangat memerlukan penerapan hukum yang tepat untuk penyelesaiannya. Tanggapan masyarakat, lembaga keagamaan, pemerintah, konvensi internasional, undang-undang yang ketat dan tindak pidana yang telah ada kerap kali gagal total dalam mengatasi ancaman tersebut. Hingga saat ini, permasalahan tersebut masih menjadi agenda nasional yang memerlukan perhatian dan keseriusan seluruh lapisan masyarakat dan pemerintahan di Aceh.

Kekerasan anak di Provinsi Aceh masih terus terjadi sepanjang siklus kehidupan dengan berbagai macam kasus yang meliputi kekerasan fisik dan mental dalam rumah, pelecehan seksual maupun pemerkosaan. Hal ini menandakan bahwa baik dari masyarakat hingga pemerintah masih belum bisa memberikan perlindungan terhadap anak-anak. Dikutip dari media Kompas.com, berdasarkan data yang diterbitkan oleh Dinas Pemberdayaan Perempuan dan Perlindungan Anak (DP3A) Provinsi Aceh, terdapat kasus kekerasan terhadap anak dengan jumlah 2.946 kasus dari tahun

${ }^{6}$ Miftahul Jannah. (2020). Peran Pembelajaran Aqidah Akhlak untuk Menanamkan Nilai Pendidikan Karakter Siswa. Al-Madrasah: Jurnal Ilmiah Pendidikan Madrasah Ibtidaiyah Vol. 4, No 2. hlm 241.

Al-Madrasah: Jurnal Ilmiah Pendidikan Madrasah Ibtidaiyah

Vol. 6, No. 1, Januari-Maret 2022 
Anggi Putri, Hardi Alunaza, Desy Nur Shafitri, Annisa Ernianda : Menilik Implementasi Qanun Pemerintah Daerah Dalam Penanganan dan Perlindungan Terhadap Kekerasan Anak di Aceh

2017-2020 yang tersebar di seluruh wilayah Provinsi Aceh ${ }^{7}$. Disebutkan pula dari data tersebut bahwa tindak kejahatan tertinggi terjadi pada kasus yang berbasis seksual dengan jumlah 1.100 kasus yang meliputi pemerkosaan, pelecehan seksual, sodomi, eksploitasi seksual dan inses.

Diagram 1. Data Kasus Kekerasan Anak di Provinsi Aceh tahun 2020.

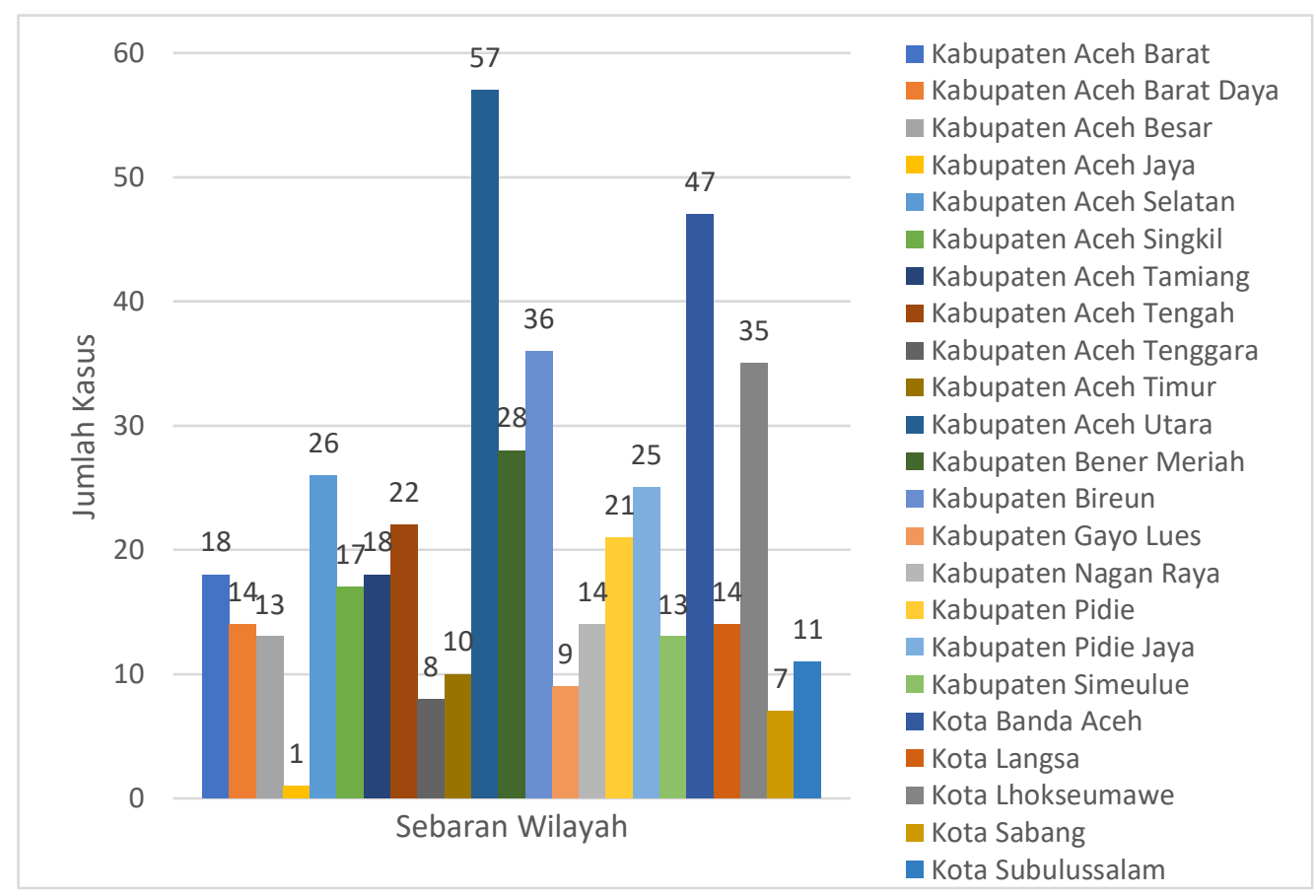

Sumber: dari Pemerintah Aceh dan diolah oleh penulis.

Data dari pemerintah Provinsi Aceh melaporkan terdapat 464 kasus kekerasan terhadap anak yang terjadi pada tahun 2020. Data ini menampilkan sebaran data dari total 23 kabupaten dan kota di Provinsi Aceh. Dari diagram di atas terlihat kasus tertinggi berasal dari Kabupaten Aceh Utara dengan jumlah 57 kasus.

Terdapat beberapa temuan kritis yang didapatkan oleh Ilan Cerna-Turoff dalam penelitiannya (2021) mengenai beberapa faktor yang menyebabkan tingginya tingkat kekerasan terhadap anak. Temuan ini meliputi 1) Data tingkat nasional tentang kekerasan terhadap anak tidak terdistribusi secara merata di seluruh negara, termasuk faktor dan jenis kekerasannya. Dengan demikian maka akan sulit bagi pemerintah untuk memfokuskan perbaikan konstitusi yang mampu mencegah terjadinya kasus kekerasan. 2) Kekerasan seksual masih belum mendapatkan perhatian lebih di dalam masyarakat. Kekerasan seksual mendapat stigma negatif di sebagian besar masyarakat, dan kurangnya dokumentasi yang setara berisiko semakin tidak terlihat dan tanggapan program serta kebijakan yang

7 Zulkarnaini. (2021). "Darurat Perlindungan Anak di Aceh". Kompas.com, diakses melalui https://www.kompas.id/baca/desk/2021/06/04/darurat-perlindungan-anak-diaceh?utm_source=kompasid\&utm_medium=link_shared\&utm_content=copy_link\&utm_campaign=sharinglink pada 2 Februari 2022.

Al-Madrasah: Jurnal Ilmiah Pendidikan Madrasah Ibtidaiyah

Vol. 6, No. 1, Januari-Maret 2022 
Anggi Putri, Hardi Alunaza, Desy Nur Shafitri, Annisa Ernianda : Menilik Implementasi Qanun Pemerintah Daerah Dalam Penanganan dan Perlindungan Terhadap Kekerasan Anak di Aceh

tidak tepat. 3) Status sosial ekonomi rumah tangga juga menjadi faktor signifikan dan kovarian yang mendorong peningkatan kekerasan emosional, fisik maupun seksual terhadap anak ${ }^{8}$.

Berfokus pada temuan pertama Ilan, dkk., komitmen serta transparansi pemerintah yang masih rendah menjadi salah satu faktor dimana kasus kekerasan anak masih tinggi di Provinsi Aceh. Kesenjangan informasi yang masih meluas di wilayah Indonesia termasuk Aceh menimbulkan tantangan dalam mengumpulkan data yang representatif. Selain itu komitmen yang dilakukan pemerintah provinsi Aceh juga masih belum serius, hal ini terlihat dari sebaran kasus kekerasan anak yang masih tinggi di seluruh wilayah provinsi Aceh.

\section{Pola penyelesaian Kasus Kekerasan Anak di Provinsi Aceh melalui Qanun Aceh}

Data empiris menunjukkan bahwa terdapat dua sumber hukum yang menyelesaikan masalah kekerasan anak dan perempuan di Aceh. Penanganan kasus kekerasan seksual terhadap anak di Aceh merujuk kepada UU Perlindungan Anak serta Peraturan Daerah Syariat Islam Qanun Jinayah. ${ }^{9}$ Peraturan dengan merujuk kepada Undang-Undang akan melakukan hukuman sesuai putusan sidang dan akan diadili sesuai peraturan yang tertera dengan sanksi denda maupun penjara. Sedangkan putusan yang didasarkan atas peraturan dalam Qanun Aceh akan memberikan hukuman berupa denda, cambuk maupun kurungan.

Faktor hukum menjadi instrumen penting dalam mempertimbangkan suatu peraturan termasuk mengenai penyelesaian kasus kekerasan anak. Berdasarkan fakta praktis, efektivitas hukum dipengaruhi oleh faktor hukum, masyarakat, penegakan hukum, sarana prasarana, dan budaya hukum. ${ }^{10}$ Dalam konteks penyelesaian kasus kekerasan anak di Aceh dipandang masih kurang efektif karena diatur menggunakan dua sumber hukum. Keadaan tersebut menyebabkan terciptanya dualisme regulasi penyelesaian sehingga dapat menimbulkan kebingungan bagi para aparat penegak hukum untuk mengajukan kasus kekerasan maupun pelecehan seksual terhadap anak, apakah harus mengajukannya kepada pengadilan negeri atau pengadilan syari'ah.

Selain ketidakpastian dalam penetapan regulasi dan birokrasi yang menjadi acuan dalam penyelesaian kasus kekerasan anak, Qanun dirasa kurang efektif karena tidak memberikan efek jera, dilihat dari hukuman yang diberikan tidak terlalu berat seperti hukuman cambuk, dan pelaku akan kembali bebas. Jika dibandingkan dengan peraturan pada UU Perlindungan Anak maka regulasi Qanun lebih lemah dalam membantu penyelesaian kasus kekerasan anak di Aceh. Untuk itu

${ }^{8}$ Cerna-Turoff I, Fang Z, Meierkord A, Wu Z, Yanguela J, Bangirana CA, Meinck F. Factors Associated With Violence Against Children in Low- and Middle-Income Countries: A Systematic Review and Meta-Regression of Nationally Representative Data. Trauma Violence Abuse. 2021 Apr;22(2):219-232. doi: 10.1177/1524838020985532. Epub 2021 Jan 19. PMID: 33461441; PMCID: PMC7961628.

${ }^{9}$ Rosmawardani Muhammad. (2020). ANALYSIS OF ABSOLUTE COMPETENCE OF DISTRICT COURTS AND SYARI'AH COURTS. PETITA: JURNAL KAJIAN ILMU HUKUM DAN SYARIAH, 5(2), hal. 147.

${ }^{10}$ Soerjono Soekanto. (2007) "Faktor-faktor yang mempengaruhi penegakan hukum.”, hal 5.

Al-Madrasah: Jurnal Ilmiah Pendidikan Madrasah Ibtidaiyah

Vol. 6, No. 1, Januari-Maret 2022 
Anggi Putri, Hardi Alunaza, Desy Nur Shafitri, Annisa Ernianda : Menilik Implementasi Qanun Pemerintah Daerah Dalam Penanganan dan Perlindungan Terhadap Kekerasan Anak di Aceh

diperlukan adanya revisi Qanun pada beberapa bagian yang dianggap kurang memberikan sanksi tegas terhadap pelaku tindak kekerasan anak tersebut.

Perbedaan peraturan yang diterapkan di Aceh untuk penanganan dan perlindungan tindak kekerasan anak-anak membuat sedikit ruang kesenjangan antara pihak-pihak tertentu yang menginginkan kesetaraan hukum yang sama. Aceh berani mengambil tindakan besar dengan menciptakan peraturan perlindungan anak pada tahun 2008 yaitu Qanun Aceh Nomor 11 Tahun 2008 mengenai perlindungan anak. Qanun perlindungan anak berwewenang untuk menyelesaikan berbagai kasus kekerasan anak bahkan dikelola langsung oleh Mahkamah Syar'iyah. Timbulnya peraturan baru untuk kekerasan anak membuat salah satu lembaga pemerintah daerah menyerahkan eksistensinya. Semenjak diberlakukan Qanun Jinayat pada kasus kekerasan seksual anak, pengadilan daerah yang harusnya menghukum pidana sesuai dengan Peraturan Undang-undang Indonesia kesulitan melakukan tugasnya. Hal ini karena wewenang penanganan kasus sepenuhnya beralih kepada Mahkamah Syar'iyah di bawah Pengadilan Agama. ${ }^{11}$

Secara birokrasi peraturan tindak pidana kekerasan anak dan penanganan perlindungan anak memicu dualisme sistem penerapan hukum di Aceh. Kewenangan lembaga yang memiliki birokrasi berbeda menimbulkan perselisihan dalam menentukan bagaimana hukum yang akan diberikan untuk perlindungan korban dan pelaku kejahatan. Jika dilihat UU Peradilan anak diterapkan oleh Pengadilan Anak di bawah Pengadilan Umum dan Qanun Jinayat oleh Mahkamah Syar'iyah dibawah Pengadilan Agama. ${ }^{12}$ Maka efektivitas dari Qanun Jinayat tidak dapat bekerja secara maksimal dalam menyelesaikan kasus-kasus kekerasan terhadap anak di Aceh. Meskipun pemerintah Aceh berusaha untuk membantu penyelesaian dengan peraturan tersebut namun sebagian masyarakat dan pemerintah daerah masih mempertimbangkan UU Peradilan Anak sebagai jalan yang lebih tepat dalam penyelesaian masalah tersebut.

\section{KESIMPULAN}

Dari penjelasan di atas dapat diketahui bahwa implementasi Qanun pemerintah daerah terkait penanganan dan perlindungan terhadap kekerasan anak di Aceh masih berada pada tahap yang kurang efektif untuk meminimalisir angka kasus kekerasan pada anak di Aceh. Kekurangan terletak pada dualisme peraturan yang diterapkan di Aceh. Tumpang tindih kewenangan antara peraturan UU pemerintah pusat dan pemerintah daerah mempersulit kinerja masing-masing peraturan tersebut. Hal ini juga memberikan dampak yang cukup membingungkan bagi masyarakat. Adanya dua regulasi

${ }^{11}$ Amrina Habibi. (2019). "Dualisme Penerapan Hukum Bagi Pelaku Kekerasan Seksual Terhadap Anak Di Provinsi Aceh." Jurnal Hukum dan Perundungan Islam. Volume 9, Nomor 1. ISSN 2089-0109. Edisi April

${ }^{12} \mathrm{Ibid}$

Al-Madrasah: Jurnal Ilmiah Pendidikan Madrasah Ibtidaiyah

Vol. 6, No. 1, Januari-Maret 2022 
Anggi Putri, Hardi Alunaza, Desy Nur Shafitri, Annisa Ernianda : Menilik Implementasi Qanun Pemerintah Daerah Dalam Penanganan dan Perlindungan Terhadap Kekerasan Anak di Aceh

yang berjalan di Aceh membuat masyarakat harus memperkirakan untuk melakukan pelaporan tindak kekerasan anak kepada Pengadilan Negeri atau Pengadilan Agama yang ada di Aceh.

\section{DAFTAR PUSTAKA}

Cerna-Turoff, I., Fang, Z., Meierkord, A., Wu, Z., Yanguela, J., Bangirana, C. A., \& Meinck, F. (2021). Factors associated with violence against children in low-and middle-income countries: a systematic review and meta-regression of nationally representative data. Trauma, Violence, \& Abuse, 22(2), 219-232.

CNN Indonesia. (2021). KemenPPPA: Kasus Kekerasan Anak dan Perempuan Meningkat di 2021. Cnnindonesia.com, diakses melalui KemenPPPA: Kasus Kekerasan Anak dan Perempuan Meningkat di 2021 (cnnindonesia.com) pada tanggal 2 Februari 2022 Pukul 10.45 WIB

Friatna, I. (2019). Perlindungan Anak dalam Perspektif Hukum Islam dan Qanun Aceh Nomor 11 Tahun 2008. Gender Equality: International Journal of Child and Gender Studies, 5(2), 5570.

Habibi, Amrina (2019). "Dualisme Penerapan Hukum Bagi Pelaku Kekerasan Seksual Terhadap Anak Di Provinsi Aceh.” Jurnal Hukum dan Perundungan Islam. Volume 9, Nomor 1. ISSN 20890109. Edisi April.

Jannah, M. (2020). Peran Pembelajaran Aqidah Akhlak Untuk Menanamkan Nilai Pendidikan Karakter Siswa. Al-Madrasah: Jurnal Pendidikan Madrasah Ibtidaiyah, 4(2), 237-252.

Kurniasari, A., Widodo, N., Yusuf, H., Susantyo, B., Wismayanti, Y. F., \& Irmayani, N. R. (2017). Prevalensi Kekerasan Terhadap Anak Laki-Laki Dan Anak Perempuan Di Indonesia. Sosio Konsepsia: Jurnal Penelitian dan Pengembangan Kesejahteraan Sosial, 6(3), 288-299.

Muhammad, R. (2020). ANALYSIS OF ABSOLUTE COMPETENCE OF DISTRICT COURTS AND SYARI'AH COURTS. PETITA: JURNAL KAJIAN ILMU HUKUM DAN SYARIAH, 5(2), 145-159.

Rino Abonita. (2021). Setiap 18 Jam 45 Menit, Satu Anak di Aceh Jadi Korban Kekerasan Seksual. Liputan6.com, diakses melalui Setiap 18 Jam 45 Menit, Satu Anak di Aceh Jadi Korban Kekerasan Seksual - Regional Liputan6.com pada tanggal 2 Februari 2022 Pukul 21.04 WIB.

Rosmawardani Muhammad. (2020). ANALYSIS OF ABSOLUTE COMPETENCE OF DISTRICT COURTS AND SYARI'AH COURTS. PETITA: JURNAL KAJIAN ILMU HUKUM DAN SYARIAH, 5(2), 145-159.

Sari, Devi Purnama. (2021). Data Kasus Kekerasan terhadap Perempuan dan Anak di Aceh Tahun 2020. Opendata, diakses melalui Data Kasus Kekerasan terhadap Perempuan dan Anak di Aceh Tahun 2020 - Datasets - OpenData Aceh (acehprov.go.id) pada tanggal 2 Februari 2022 pukul 17.20 WIB.

SIMFONI-PPA. (2021). Rasio Anak Korban Kekerasan (Per 10.000 Anak). Kementerian Pemberdayaan Perempuan dan Perlindungan Anak Republik Indonesia, diakses melalui SIMFONI-PPA (kemenpppa.go.id) pada tanggal 2 Februari 2022 pukul 10.08 WIB

Suhairu, Sapri. (2019). "Perlindungan Hukum Terhadap Anak Korban Tindak Pidana Sodomi (Studi Kasus di Desa Alue Buloh Aceh Timur)." Jurnal Ilmiah Mahasiswa. Vol.1,No.2. Edisi Desember.

Vonda, Pocut Ismyati \& Cut Dian Fitri. (2017). "Pelaksanaan Perlindungan Anak di Kota Banda Aceh." Gender Equality:International Journay od Child and Gender Studies. Vol.3, No.1 Edisi Maret.

Zulkarnaini. (2021). "Darurat Perlindungan Anak di Aceh". Kompas.com, diakses melalui https://www.kompas.id/baca/desk/2021/06/04/darurat-perlindungan-anak-di-

Al-Madrasah: Jurnal Ilmiah Pendidikan Madrasah Ibtidaiyah

Vol. 6, No. 1, Januari-Maret 2022 
Anggi Putri, Hardi Alunaza, Desy Nur Shafitri, Annisa Ernianda : Menilik Implementasi Qanun Pemerintah Daerah Dalam Penanganan dan Perlindungan Terhadap Kekerasan Anak di Aceh

aceh?utm_source=kompasid\&utm_medium=link_shared\&utm_content=copy_link\&utm_cam paign=sharinglink pada 2 Februari 2022.

Al-Madrasah: Jurnal Ilmiah Pendidikan Madrasah Ibtidaiyah

Vol. 6, No. 1, Januari-Maret 2022 